\title{
NONSPECIFIC SPONDYLODISCITIS IN ADULTS: RETROSPECTIVE STUDY
}

\author{
ESPONDILODISCITES INESPECÍFICAS EM ADULTOS: ESTUDO RETROSPECTIVO
}

ESPONDILODISCITIS INESPECÍFICAS EN ADULTOS: ESTUDIO RETROSPECTIVO

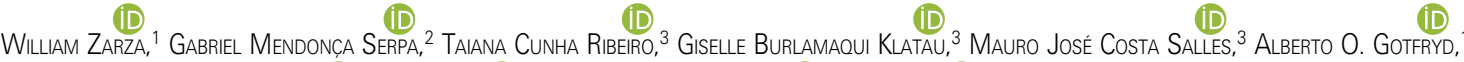 \\ Rodrigo Góes Medéa de Mendonça, ${ }^{1}$ Nelson Astur, ${ }^{1}$ Maria Fernanda S. Caffaro, ${ }^{1}$ Robert Meves ${ }^{1}$ \\ 1. Irmandade da Santa Casa de Misericórdia de São Paulo, Department of Orthopedics and Traumatology, Spinal Disorders Group, São Paulo, SP, Brazil. \\ 2. Faculdade de Ciências Médicas Santa Casa de São Paulo, São Paulo, SP, Brazil. \\ 3. Irmandade da Santa Casa de Misericórdia de São Paulo, Department of Infectology, São Paulo, SP, Brazil.
}

\begin{abstract}
Objective: To describe the epidemiological and clinical characteristics of patients with pyogenic spondylodiscitis treated in a Brazilian hospital. Methods: This is a retrospective study of patients diagnosed with nonspecific spondylodiscitis. Patients of both sexes, above 18 years of age with a minimum follow-up time of 6 months were included. Epidemiological, laboratory, and clinical data were analyzed. Results: Nine patients were included. The mean age was 64 years, with seven men (77.7\%) and two women (22.2\%). All patients evaluated had back pain. The most affected location was the lumbar spine (44.4\%). Only three patients (33.3\%) had fever and five (55\%) had constitutional symptoms. The mean duration of symptoms before diagnosis was 2.5 ( \pm 1.5$)$ weeks. Only four patients $(44.4 \%)$ had positive cultures. As for neurological status, five patients (55.5\%) presented neurological change. At the end of treatment, two patients improved one level in the Frankel score and two patients improved two levels. The main indication for surgery was neurological deficit (55.5\%). Two of the patients evaluated died as a result of an infectious condition. Conclusions: Less than half of the patients with pyogenic spondylodiscitis had fever or constitutional symptoms. Back pain was present in all cases. In less than half of the patients it was possible to isolate the responsible microorganism. Most patients underwent surgical treatment, although not all improved from the neurological deficit. Level of evidence II; Retrospective study.
\end{abstract}

Keywords: Spinal Diseases; Discitis; Intervertebral Disc.

\section{RESUMO}

Objetivo: Descrever as características epidemiológicas e clínicas de pacientes com espondilodiscite piogênica tratados em um hospital brasileiro. Métodos: Trata-se de estudo retrospectivo de pacientes com diagnóstico de espondilodiscite inespecífica. Foram incluídos pacientes de ambos os sexos, acima de 18 anos, com tempo de seguimento mínimo de seis meses. Foram analisados dados epidemiológicos, laboratoriais e clínicos. Resultados: Nove pacientes foram incluídos. A média de idade foi de 64 anos, sendo sete homens (77,7\%) e duas mulheres (22,2\%). Todos os pacientes avaliados tinham dorsalgia. O local mais acometido foi a coluna lombar (44,4\%). Apenas três pacientes (33,3\%) apresentaram febre e cinco (55\%), sintomas constitucionais. O tempo médio de sintomas antes do diagnóstico foi de $2,5( \pm 1,5)$ semanas. Apenas quatro pacientes $(44,4 \%)$ tiveram culturas positivas. Cinco pacientes $(55,5 \%)$ apresentaram alteração neurológica. Ao término do tratamento, dois pacientes melhoraram um nível no escore de Frankel, dois pacientes melhoraram dois níveis. A principal indicação para cirurgia foi déficit neurológico (55,5\%). Dois pacientes avaliados foram a óbito em decorrência do quadro infeccioso. Conclusões: Menos da metade dos pacientes com espondilodiscite piogênica tiveram febre ou sintomas constitucionais. A dorsalgia estava presente em todos os casos. Em menos da metade dos pacientes foi possível isolar o microrganismo responsável. A maioria dos pacientes foi submetida a tratamento cirúrgico, embora nem todos tiveram melhora do déficit neurológico. Nível de evidência II; Estudo Retrospectivo.

Descritores: Doenças da Coluna Vertebral; Discite; Disco Intervertebral.

\section{RESUMEN}

Objetivo: Describir las características epidemiológicas y clínicas de pacientes con espondilodiscitis piógena tratados en un hospital brasileño. Métodos: Se trata de un estudio retrospectivo de pacientes con diagnóstico de espondilodiscitis inespecífica. Fueron incluidos pacientes de ambos sexos, mayores de 18 años, con tiempo de seguimiento mínimo de seis meses. Fueron analizados datos epidemiológicos, de laboratorio y clínicos. Resultados: Se incluyeron nueve pacientes. El promedio de edad fue de 64 años, siendo siete hombres (77,7\%) y dos mujeres (22,2\%). Todos los pacientes evaluados tenían dolor de espalda. El local más acometido fue la columna lumbar (44,4\%). Sólo tres pacientes $(33,3 \%)$ presentaron fiebre y cinco (55\%) síntomas constitucionales. El tiempo promedio de síntomas antes del diagnóstico fue de 2,5 ( \pm 1,5) semanas. Sólo cuatro pacientes $(44,4 \%)$ tuvieron cultivos positivos. Cinco pacientes (55,5\%) presentaron alteración neurológica. Al término del tratamiento, dos pacientes mejoraron un nivel en la escala de Frankel, dos pacientes mejoraron dos niveles. La principal indicación para cirugía fue el déficit neurológico (55,5\%). Dos pacientes evaluados fueron a óbito como consecuencia del cuadro infeccioso. Conclusiones: Menos de la mitad de los pacientes con espondilodiscitis piógena tuvieron fiebre o síntomas constitucionales. El dolor de espalda estuvo presente en todos los casos. En menos de la mitad de los pacientes fue posible aislar el microorganismo responsable. La mayoría de los pacientes fue sometida a tratamiento quirúrgico, aunque no todos tuvieron mejora del déficit neurológico. Nivel de evidencia II; Estudio retrospectivo.

Descriptores: Enfermedades de la Columna Vertebral; Discitis; Disco Intervertebral.

Study conducted at the Irmandade da Santa Casa de Misericórdia de São Paulo. Rua Dr. Cesário Mota Junior, 112, Vila Buarque, São Paulo, SP, Brasil. 01221-020.

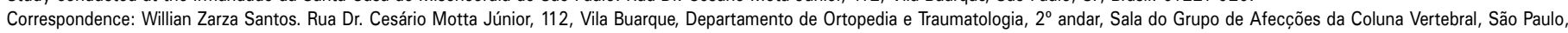
SP, Brasil. 01221-020. willzarza@yahoo.com.br 


\section{INTRODUCTION}

Spondylodiscitis comprises a spectrum of manifestations that includes infections of the vertebral body, known as vertebral osteomyelitis; of the intervertebral disc, known as discitis; and, finally, infections involving the posterior vertebral elements, corresponding to spondylitis. ${ }^{1}$

The diagnosis of pyogenic spondylodiscitis is difficult and often late, due to its deceptive clinical presentation. ${ }^{2-4}$ Moreover, initial low back pain symptoms may be overlooked by the physician because of their high prevalence in the general population and because the disease in question is not common..$^{2,4}$

For the correct and earliest possible diagnosis, suspicion is fundamental. A detailed clinical history to search for risk factors together with a thorough physical examination are essential steps in diagnosis. ${ }^{2,3,5}$ Laboratory tests are important, especially for inflammatory markers, such as the erythrocyte sedimentation rate (ESR) and c-reactive protein (CRP). ${ }^{4,5}$

Spinal radiographs are the first diagnostic imaging examination, though they have low specificity for spondylodiscitis. ${ }^{4,5}$ Magnetic resonance is the gold standard imaging examination in diagnosis, with $96 \%$ sensitivity and $94 \%$ specificity, ${ }^{4,5}$ however, it is often unavailable in Brazilian hospitals. These two factors contribute to the difficulty in diagnosing vertebral infection.

The objective of this study is to evaluate the epidemiological characteristics of adults with non-specific spondylodiscitis and its clinical evolution following medical treatment.

\section{METHODS}

A retrospective epidemiological study was conducted after approval by the Institutional Review Board of a quaternary hospital in the city of São Paulo. Data collection was accomplished through analysis of the medical records of patients treated at the institution from October 2015 to May 2019

The study was authorized by the Institutional Review Board (CAAE: 93695218.8.0000.5479) and the participants who met the inclusion criteria signed the informed consent form (Attachment I) after having been informed about the nature of the research. In this document, information was provided about the objectives of the study in layman's terms and the option to abandon participation in the study without harm to the participant was ensured.

Cases that presented clinical, laboratory, and radiological results compatible with intervertebral disc infection were considered non-specific spondylodiscitis, without a requirement for positive anatomopathological or microbiological test results.

\section{The inclusion criteria were:}

- Patients of both sexes

- Age over 18 years

- Diagnosis of non-specific spondylodiscitis

- Minimum follow-up of 6 months

\section{The exclusion criteria were:}

- Patients with a diagnosis of specific spondylodiscitis

- Patients who had undergone procedures with spinal implants

- Cases with incomplete medical records

The following epidemiological data were analyzed: time from symptoms, such as back pain, fever, drop in overall health, and neurological damage, age, sex, and associated comorbidities, to diagnosis. A laboratory evaluation and an analysis of blood and tissue cultures were conducted. Treatment-related data, such as duration of antibiotic therapy and the need for surgical treatment, as well as the procedure performed, were also studied. The diagnostic imaging methods used were anteroposterior and lateral radiographs and/or computed tomography and/or magnetic resonance of the affected segment. (Figures 1 and 2)

Finally, clinical evolution data, such as presence of residual pain, deformity, neurological deficit, ${ }^{6}$ and death were analyzed.
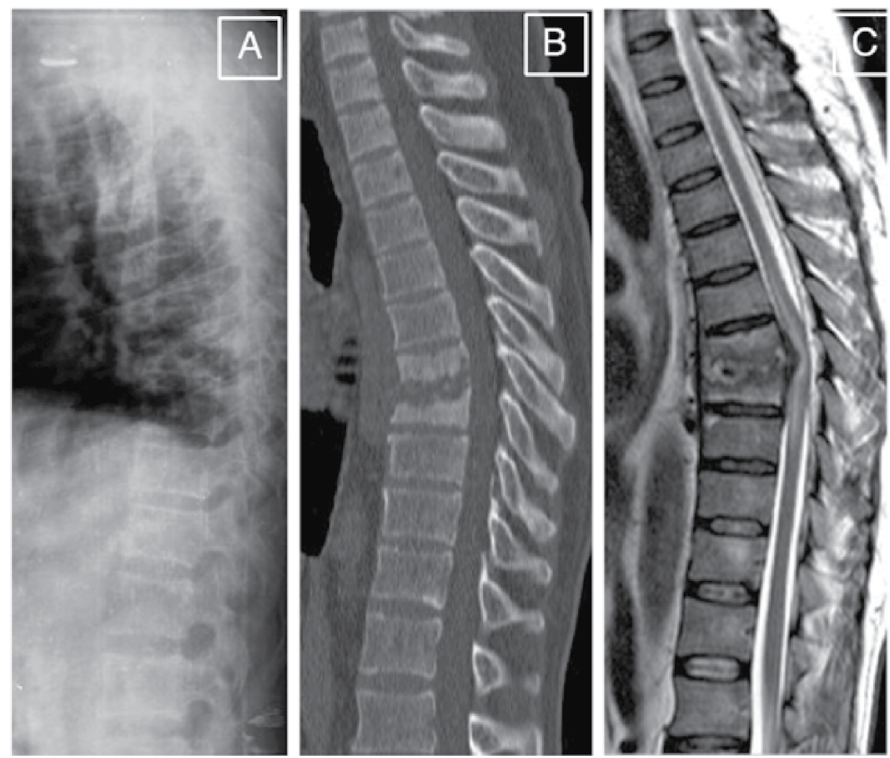

Figure 1. Male, 47 years of age, experiencing paraplegia for 10 days. A: Radiograph with involvement of the vertebral body of T7 and T8. B: Sagittal tomography showing destruction of the endplates. C: MR showing medullary compression.
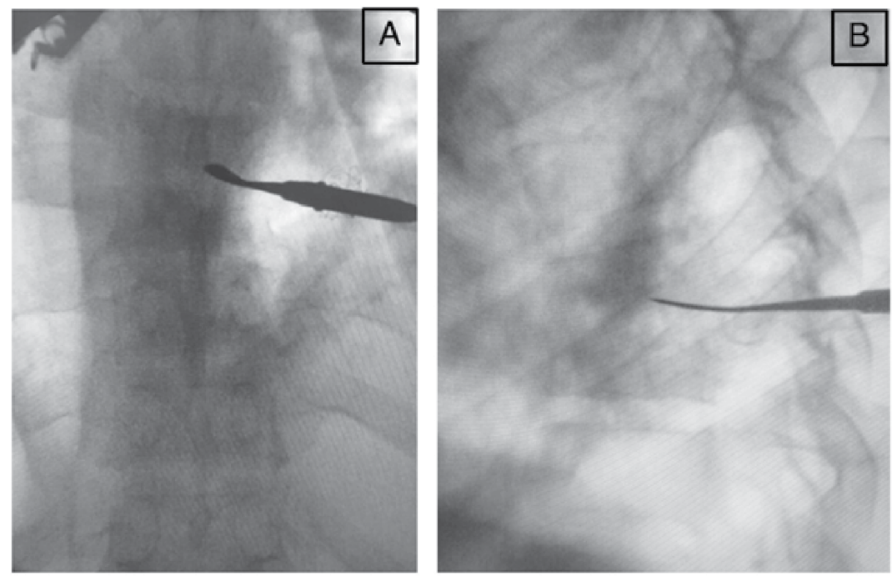

Figure 2. Patient submitted to posterolateral approach medullary decompression (costotransversectomy) who progressed with a two-grade improvement on the Frankel scale. A and B: Intraoperative fluoroscopy showing the Penfield location and the access to the vertebral body after spinal canal decompression.

Statistical analysis involved the quantification of descriptive data as means and standard deviations for continuous variables and as percentages for categorical variables, using SPSS Statistics 21 software.

\section{RESULTS}

Eleven patients with a diagnosis of non-specific spondylodiscitis were identified during the period from 2015 to 2019. Two of these were excluded because they were children. Therefore, the case series had nine patients. The mean age was 64 years and there were seven men (77.7\%) and two women (22.2\%). Associated comorbidities and other epidemiological characteristics of the cases are described in Table 1.

\section{Clinical and Laboratory Presentation}

Back pain was present in all the patients evaluated. The lumbar spine was the most often affected location with four patients (44.4\%), followed by the thoracic region with three patients (33.3\%), and the thoracolumbar transition with two patients (22.2\%). Three patients (33.3\%) presented fever and five presented constitutional symptoms, such as 
weight loss, adynamia, or drop in general state of health. The mean symptom time was $2.5( \pm 1.5)$ weeks. In the laboratory evaluation, the mean hemoglobin count was $11.2( \pm 1.5)$, the leukocyte count was 8.7 ( \pm 3.5$)$, and the mean values of inflammatory markers, such as CRP and ESR, were $55.9( \pm 43.3)$ and $92( \pm 21.9)$, respectively. Four patients (44.4\%) had positive blood and/or tissue cultures. The clinical and laboratory data are summarized in Tables 2 and 3, respectively.

\section{Evaluation of neurological status}

At the time of diagnosis, four patients (44.4\%) presented no neurological changes (Frankel E), one patient had non-useful motor function (Frankel C), three patients had sensory function but no motor function below the level of the lesion (Frankel B), and one patient had complete neurological damage (Frankel A). At the end of treatment, five patients remained with their initial neurological examination scores unchanged, two patients improved by one Frankel score level, and two patients improved by two score levels. (Table 4) No patient presented deterioration of their initial neurological status either during or after treatment.

Table 1. Descriptive data.

\begin{tabular}{|c|c|}
\hline & Total \\
\hline Sample size & $9(100 \%)$ \\
\hline Age & 64 years \\
\hline \multicolumn{2}{|l|}{ Sex } \\
\hline Female & $2(22.3 \%)$ \\
\hline Male & $7(77.7 \%)$ \\
\hline \multicolumn{2}{|l|}{ Smoke } \\
\hline Yes & $1(11.1 \%)$ \\
\hline No & $8(88.9 \%)$ \\
\hline \multicolumn{2}{|l|}{ Alcohol use } \\
\hline Yes & $1(11.1 \%)$ \\
\hline No & $8(88.9 \%)$ \\
\hline \multicolumn{2}{|c|}{ High Blood Pressure (HBP) } \\
\hline Yes & $7(77.8 \%)$ \\
\hline No & $2(22.2 \%)$ \\
\hline \multicolumn{2}{|l|}{ HIV } \\
\hline Positive & $0(0 \%)$ \\
\hline Negative & $9(100 \%)$ \\
\hline \multicolumn{2}{|l|}{ Neoplasia } \\
\hline Yes & $2(22.2 \%)$ \\
\hline No & $7(77.8 \%)$ \\
\hline \multicolumn{2}{|c|}{ Chronic Renal Failure (CRF) } \\
\hline Yes & $1(11.1 \%)$ \\
\hline No & $8(88.9 \%)$ \\
\hline \multicolumn{2}{|l|}{ Diabetes } \\
\hline Yes & $2(22.2 \%)$ \\
\hline No & $7(77.8 \%)$ \\
\hline
\end{tabular}

Table 2. Clinical presentation.

\begin{tabular}{c|c}
\hline & Total \\
\hline Presence of pain & $9(100 \%)$ \\
\hline Yes & $0(0 \%)$ \\
\hline No & $3(33.3 \%)$ \\
\hline Location of the painful area & $2(22.2 \%)$ \\
\hline Thoracic spine & $4(44.4 \%)$ \\
\hline Thoracolumbar transition & $2.5( \pm 1.5)$ \\
\hline Lumbar spine & $3(33.3 \%)$ \\
\hline Time of symptoms (weeks) & $6(66.7 \%)$ \\
\hline Yeser & $5(55.5 \%)$ \\
\hline No & $4(44.4 \%)$ \\
\hline Yes &
\end{tabular}

\section{Evaluation of surgical treatment}

Only one patient in the present study did not undergo surgery, having been treated only via antibiotic therapy. The main indication for performing a surgical procedure was neurological deficit in five patients (55.5\%); the other three patients underwent surgery after clinical treatment failed. Of the procedures performed, three were minimally invasive biopsy, two patients underwent decompressive laminectomy, another two patients underwent posterolateral approach decompression (costotransversectomy), and one patient underwent decompression and posterior arthrodesis. (Table 5)

\section{Evaluation of complications}

Two patients died. One of them had chronic kidney disease requiring dialysis and died as a result of clinical complications from the baseline disease. The other patient, a diabetic, died due to clinical issues resulting from prolonged hospitalization. Regarding complications in the seven other patients, three presented neurological deficits with impaired useful motor function (Frankel A, B, or C), three remained with residual back pain, and one case presented kyphotic deformity at the site affected by the spondylodiscitis. (Table 6)

Table 7 shows the summarized epidemiological data for each patient included in the study.

Table 3. Laboratory tests.

\begin{tabular}{c|c|c|c}
\hline & Participants & Mean & $\begin{array}{c}\text { Standard } \\
\text { deviation }\end{array}$ \\
\hline Hemoglobin & - & 11.2 & 1.57 \\
\hline Leukocytes & - & 8.77 & 3.57 \\
\hline C-Reactive Protein & - & 55.9 & 43.3 \\
\hline Erythrocyte sedimentation rate (ESR) & - & 92 & 21.9 \\
\hline Total & 9 & & \\
\hline Anatomopathological Test & & & \\
\hline Negative & $5(55.6 \%)$ & & \\
\hline Positive & $4(44.4 \%)$ & & \\
\hline & & &
\end{tabular}

Table 4. Evaluation of neurological status.

\begin{tabular}{c|c|c}
\hline & Initial & Final \\
\hline$A$ & $1(11.1 \%)$ & $0(0 \%)$ \\
\hline$B$ & $3(33.3 \%)$ & $1(11.1 \%)$ \\
\hline$C$ & $1(11.1 \%)$ & $2(22.2 \%)$ \\
\hline$D$ & $0(0 \%)$ & $2(22.2 \%)$ \\
\hline$E$ & $4(44.4 \%)$ & $4(44.4 \%)$ \\
\hline
\end{tabular}

Table 5. Evaluation of surgical treatment.

\begin{tabular}{c|c}
\hline & Total \\
\hline Surgical Indication & $5(55.6 \%)$ \\
\hline Neurological deficit & $3(33 \%)$ \\
\hline Failure of drug treatment & $2(22.2 \%)$ \\
\hline Procedure performed & $3(33.3 \%)$ \\
\hline Laminectomy & $1(11.1 \%)$ \\
\hline Minimally invasive biopsy & $2(22.2 \%)$ \\
\hline Arthrodesis + laminotomy & \\
\hline Costotransversectomy & $9.4( \pm 4.1)$ \\
\hline Treatment time (weeks) &
\end{tabular}

\pm -> Standard deviation.

Table 6. Complications

\begin{tabular}{c|c}
\hline & Total \\
\hline Complications & \\
\hline Residual pain & $3(33.3 \%)$ \\
\hline Neurological deficit (Frankel A, B or C) & $3(33.3 \%)$ \\
\hline Deformity & $1(11.1 \%)$ \\
\hline Death & $2(22.2 \%)$ \\
\hline
\end{tabular}


Table 7. Epidemiological table - Summarized cases

\begin{tabular}{|c|c|c|c|c|c|c|c|c|c|}
\hline Case & Age & Sex & Location & $\begin{array}{c}\begin{array}{c}\text { Time of symptoms } \\
\text { (weeks) }\end{array} \\
\end{array}$ & $\begin{array}{c}\text { Asia } \\
\text { Initial/final }\end{array}$ & $\begin{array}{c}\text { Culture (positive } \\
\text { or not) }\end{array}$ & $\begin{array}{c}\text { Treatment } \\
\text { (surgical or not) }\end{array}$ & Type of surgery & Death \\
\hline 2 & 72 & $F$ & $\mathrm{~L}$ & 2 & $\mathrm{E} / \mathrm{E}$ & No & Surgical & $\mathrm{B}$ & No \\
\hline 4 & 52 & $\mathrm{M}$ & $\mathrm{L}$ & 2 & $\mathrm{E} / \mathrm{E}$ & Yes & Surgical & $\mathrm{B}$ & No \\
\hline 5 & 73 & $\mathrm{M}$ & $T$ & 2 & $E / E$ & No & No & - & No \\
\hline 6 & 47 & $\mathrm{M}$ & $T / L$ & 1 & $B / D$ & Yes & Surgical & CT & No \\
\hline 9 & 70 & $\mathrm{M}$ & $\mathrm{T}$ & 1 & $\mathrm{~B} / \mathrm{C}$ & Yes & Surgical & $\mathrm{CT}$ & No \\
\hline
\end{tabular}

Key: T: Thoracic; T/L: Thoracolumbar; L: Lumbar; LM: Laminectomy; B: Biopsy. LM+A: Laminectomy + Arthrodesis; CT: Costotransversectomy

\section{DISCUSSION}

Patients with non-specific spondylodiscitis were retrospectively evaluated over a four-year period. Because this was a relatively short period and the disease is rare,,$^{2,4}$ we obtained a total of only nine patients. Their mean age was 64 years, which is consistent with the literature, where the most affected age group respects a bimodal distribution of under 20 and between 50 and 70 years of age. . $^{2,3}$ As for sex, most cases were in males (77.7\%), which is also in agreement, since men are affected three times more than women. ${ }^{1-3}$

Regarding the clinical diagnosis, all patients in the present study complained of back pain and 33\% of them had a fever. As for location, the most affected region was the lumbar spine, followed by the thoracic region and the thoracolumbar transition. In a retrospective case series with one hundred and five patients with pyogenic spondylodiscitis, Loibl et al. ${ }^{7}$ reported a prevalence of $66.7 \%$ of back pain in their patients, 33.3\% had fever, and the most affected location was the lumber spine with approximately $58 \%$ of cases, followed by the thoracic region and the thoracolumbar transition, as in this series. In the present study there were no patients with cervical spine involvement, which may be explained by the reduced sample size, but also by the low incidence of this topography, which ranges from 3-11\% of all discities. ${ }^{8}$

As regards the laboratory diagnosis, only $44.4 \%$ had positive cultures. This agrees with the study by Loibl, ${ }^{7}$ which found $46.5 \%$ with positive cultures, and the series of Parra et al., ${ }^{9}$ with one hundred and eight patients, in which the positivity of cultures was only $50 \%$.

Parra et al., ${ }^{9}$ also reported that, of the one hundred and eight cases with infectious spondylodiscitis evaluated, one hundred patients (89.8\%) presented single-level involvement, which agrees with what we observed in our sample, since only one of the nine study patients had involvement at more than one level in the spine, denoting that, in fact, most cases of non-specific spondylodiscitis have the characteristic of affecting only one level.

As for the period of time between the onset of the manifestation of symptoms and diagnosis, it is well-established in the literature that this is long, ranging from 8 to 24 weeks, ${ }^{2,3}$ which was not found in our sample, where the mean time was 2.5 weeks. This divergence may be explained by the fact that five of the nine patients had neurological deficit at the beginning of the monitoring of their cases, which facilitated the diagnosis. In Bettini's series, ${ }^{3}$ only three of the fifty-six patients evaluated had neurological deficit, which may explain their greater mean time from symptoms to diagnosis, which was ten weeks.

As for the risk factors associated with symptoms of severe neurological deficit, Lemaignen et al., ${ }^{10}$ in their case-control study with three hundred and seventy-eight patients, concluded that the factors associated with worse neurological prognosis are a Charlson Score ${ }^{11}$ higher than five points, severity of the initial motor weakness (Frankel A and B), and involvement of the thoracic spine. Furthermore, they associated involvement of the lumbar spine with a favorable outcome. When evaluating neurological status in the present study, we noted that of the five patients who remained with some degree of neurological deficit, four had thoracic or thoracolumbar spine involvement and four were initially classified as A or B on the Frankel scale. Additionally, of the four patients with lumbar involvement, three were Frankel $E$ and one was Frankel $D$ at the end of treatment. This seems to indicate that lumbar involvement is a factor of good prognosis, as proposed by Lemaignen. ${ }^{10}$

In addition to neurological deficit, residual deformity is a concern to be considered in the treatment of spinal infections. ${ }^{12}$ In a retrospective cohort study of forty-eight patients, Srinivasan et al., ${ }^{12}$ evaluated risk factors associated with the development of deformity in patients with spinal infections and identified only one significant variable related to deformity: the location of the infection (osteomyelitis, discitis, or epidural abscess). The patients with vertebral and/ or disc involvement without an epidural abscess had higher chances of developing a deformity than the patients with an abscess. ${ }^{12}$ One patient in our case series presented kyphotic deformity in the thoracic spine and did not have an epidural abscess, but only disc involvement, which is in agreement with Srinivasan's findings. ${ }^{12}$

The best surgical strategy in the treatment of spondylodiscitis is a widely discussed topic. In our service, we frequently use posterolateral costotransversectomy decompression, indicated mainly in cases with thoracic involvement without signs of instability. In the present study, two patients underwent costotransversectomy. Initially, both had a Frankel B score and, following surgery, one patient progressed to Frankel $\mathrm{C}$ and the other to Frankel D. (Figures 1 and 2) Cheng et al. ${ }^{13}$ compared the isolated posterior approach (transforaminal or costotransversectomy) with the anterior approach combined with posterior fixation. They concluded that the isolated posterior approach could prevent complications and postoperative respiratory problems associated with anterior approaches, in addition to being an excellent alternative for patients with medical comorbidities and less tolerance for long-term anesthesia and substantial blood loss.

Although the literature is prolific, there are still not enough data to define good guidelines for the diagnosis and treatment of non-specific spondylodiscitis. ${ }^{14}$ In their broad systematic review on the topic, Rutges et al., ${ }^{14}$ selected twenty-five studies, but of these only five were considered to have a good level of evidence and a strong recommendation, a fact that demonstrates the poor quality of publications. In addition, studies of Brazilian patients tend to evaluate pyogenic spondylodiscitis and tuberculosis jointly in the same sample. ${ }^{15,16} \mathrm{~A}$ strong point of our study is the homogeneity of the sample, since we excluded specific discites. The main limitations of the study are the restricted size of the sample and the fact that it is a retrospective work.

\section{CONCLUSION}

In the study sample less than half of the patients with pyogenic spondylodiscitis had fever or other constitutional symptoms. Back pain was present in all cases. Isolation of the responsible microorganism was possible in less than half of the patients. Most patients underwent surgical treatment, although not all improved from the neurological deficit resulting from the spinal infection.

All authors declare no potential conflict of interest related to this article. 
CONTRIBUTION OF THE AUTHORS: Each author made significant individual contributions to this manuscript. WZ: writing and data analysis; RM: data analysis and review; MFSC: data analysis and review; AOG: data analysis, writing, and review; NA: data analysis and review; RGMM: data analysis and review; GMS: data analysis; TCR: data analysis and review; GBK: data analysis and review; MJCS: data analysis and review.

\section{REFERENCES}

1. Herrero CFPS, do Nascimento AL, Cunha RP, Souza JPV, Nogueira-Barbosa MH, Defino HLA Infectious spondylodiscitis: Has there been any evolution in the diagnostic and treatment outcomes? Coluna/ Columna. 2014;13(4):294-7.

2. Costa J, de Andrade N, Arcangelo J, Pedrosa C, Figueira P. Espondilodiscite piogénica em adultos: diagnóstico e tratamento. Rev Port Ortop e Traumatol. 2015;23(3):225-35.

3. Bettini N, Girardo M, Dema E, Cervellati S. Evaluation of conservative treatment of non specific spondylodiscitis. Eur Spine J. 2009;18(Suppl 1):143-50.

4. Gouliouris T, Aliyu SH, Brown NM. Spondylodiscitis: Update on diagnosis and management J Antimicrob Chemother. 2010;65 Suppl 3:iii11-24.

5. Duarte RM, Vaccaro AR. Spinal infection: State of the art and management algorithm. Eur Spine J. 2013;22(12):2787-99.

6. Frankel HL, Hancock DO, Hyslop G, Melzak J, Michaelis LS, Ungar GH, et al. The value of postural reduction in the initial management of closed injuries of the spine with paraplegia and tetraplegia. Paraplegia. 1969;7(3):179-92.

7. Loibl M, Stoyanov L, Doenitz C, Brawanski A, Wiggermann P, Krutsch M, et al. Outcomerelated co-factors in 105 cases of vertebral osteomyelitis in a tertiary care hospital. Infection. 2014;42(3):503-10.

8. Barnes B, Alexander J, Branch C. Cervical osteomyelitis: a brief review. Neurosurg Focus 2004;17(6): 11-3

9. Parra JLC, Martín ASA, Martínez-Aedo ALU, Ivañez IS, Agreda E, Stern LLD. Management of infectious discitis. Outcome in one hundred and eight patients in a University Hospital. Int Orthop. 2012;36(2):239-44

10. Lemaignen A, Ghout I, Dinh A, Gras G, Fantin B, Zarrouk V, et al. Characteristics of and risk factors for severe neurological deficit in patients with pyogenic vertebral osteomyelitis. Medicine (Baltimore). 2017;96(21):e6387.

11. Charlson M, Szatrowski TP. Peterson J, Gold J. Validation of a combined comorbidity index J Clin Epidemiol. 1994;47(11):1245-51.

12. Srinivasan D, Terman SW, Himedan M, Dugo D, La Marca F, Park P. Risk factors for the development of deformity in patients with spinal infection. Neurosurg Focus. 2014:37(2):1-6

13. Kao FC, Tsai TT, Niu CC, Lai PL, Chen LH, Chen WJ. One-stage posterior approaches for treatment of thoracic spinal infection. Medicine (Baltimore). 2017;96(42):e8352.

14. Rutges JPHJ, Kempen DH, van Dijk M, Oner FC. Outcome of conservative and surgical treatment of pyogenic spondylodiscitis: a systematic literature review. Eur Spine J. 2016;25(4):983-99.

15. Finger G, Cecchini AML, Sfreddo $E$, Cecchini FML, Lunardi LW, Nascimento $T L$, et al. Spondylodiscitis Investigation and Therapeutic Protocol: Neurosurgery Service Results. Coluna/Columna. 2019;18(2):138-43.

16. da Silva Junior JP, Pereira AFF, Silveira LL, Ferreira MAC, Rangel TAM. Perfil epidemiológico e avaliação da resposta ao tratamento cirúrgico nos pacientes com espondilodiscite atendidos no serviço de cirurgia da coluna do hospital getúlio vargas em recife. Coluna/ Columna. 2011;10(4):279-83. 